\title{
Modelling for rearrangement of fusiform initials during radial growth of the vascular cambium in Pinus sylvestris $\mathbf{L}$.
}

\author{
Wiesław Włoch · Anna Wilczek · Joanna Jura-Morawiec • \\ Paweł Kojs $\cdot$ Muhammad Iqbal
}

Received: 9 October 2012/Revised: 20 December 2012/ Accepted: 8 January 2013/Published online: 13 February 2013

(C) The Author(s) 2013. This article is published with open access at Springerlink.com

\begin{abstract}
In contrast to common belief, recent studies have confirmed that intrusive growth of fusiform cambial initials has a significant role in the rearrangement of the initials, but does not contribute to the cambial circumference increment. We observed a rapid rearrangement of cambial initials on a long series of transverse sections of the vascular cambium and the wood of a 50-year-old pine (Pinus sylvestris L.) tree. A comparison of cell arrangement in consecutive sections, as well as a critical analysis of tangential reconstructions, has confirmed that changes in cell locations in a group of cells on the tangential surface caused no change in the total tangential width of the whole group. Models illustrating changes in locations of the initials have been proposed, assuming that intrusive growth, which makes the growing initials intrude between the neighbouring initials and their immediate derivatives, is localized on the longitudinal edges of cells. We infer that intrusive growth of the cambial initials in $P$. sylvestris is not involved in the cambial circumference increment, but plays a significant role in the rearrangement of the initials, probably allowing for a relaxation of shearing strains generated during radial growth. The relationship of
\end{abstract}

Communicated by R. Aloni.

W. Włoch · A. Wilczek $(\bowtie)$

Department of Biosystematics, University of Opole,

Oleska 22, 40-052 Opole, Poland

e-mail: anna.wilczek@uni.opole.pl; a.wilczek@vp.pl

W. Włoch · J. Jura-Morawiec · P. Kojs

Polish Academy of Sciences Botanical Garden,

Centre for Biological Diversity Conservation, Prawdziwka 2,

Powsin, 02-973 Warsaw 76, Poland

M. Iqbal

Department of Botany, Jamia Hamdard (Hamdard University),

New Delhi 110062, India intrusive growth with the elimination of initials has been discussed with reference to the frequency of anticlinal divisions. It has been proposed that the occurrence of anticlinal divisions in excess over the actual requirement for increase in the cambial circumference could be due to internal shearing strains.

Keywords Vascular cambium · Circumference . Rearrangement · Intrusive growth · Models ·

Pinus sylvestris

\section{Introduction}

In the world, there are millions of square kilometres of vascular cambium - a fine layer of meristematic cells that form wood, layer after layer, just like the tiny corals that form a huge coral reef. Wood is one of the most fascinating natural resources that forms the backbone of several industries all over the globe. Although much research has focused on wood, the vascular cambium, which is responsible for producing each cell in the wood, has hardly received enough attention. It is now known that the rearrangement of cambial initials influences the properties of wood (e.g. the grain in wood) and, therefore, understanding the mechanism of this cambial cell rearrangement becomes immensely important.

In this paper the cambium is considered in its broad sense as a multilayered meristematic cylinder around the wood core. The characteristic divisions, intrusive growth, as well as symplastic growth of cambial initials contribute markedly to the formation of wood patterns. Intrusive growth is peculiarly characteristic of cambial initials and the developing fibres and vessel elements, and occurs only occasionally in other plant cells (Lev-Yadun 2001). In 
general, intrusive growth of cambial initials is believed to contribute to the circumferential growth of the cambium (Sinnot and Bloch 1939; Majmudar 1941; Bannan 1950, 1956; Hejnowicz 1961, 1968; Iqbal 1990; Larson 1994; Evert 2006). If that is so, the intrusively growing initial should grow between the anticlinal walls of its neighbouring initials. But this assumption is unable to explain phenomena such as the rapid rearrangement of initials in the old stem cambia (Włoch and Połap 1994; Włoch et al. 2002; Karczewska et al. 2009) or the tumorous cambia (Włoch 1976; Włoch et al. 2001). According to newer findings, intrusive growth of the cambial initial occurs between the tangential walls of neighbouring initial cells and their immediate derivatives and, therefore, does not contribute to the circumferential enlargement of the cambial cylinder (Włoch et al. 2001, 2002, 2009; Kojs et al. 2004a, b; Jura et al. 2006; Karczewska et al. 2009; Wilczek et al. 2011). In fact, two adjacent initials (one growing intrusively, the other being eliminated) temporarily compete for the same area of initial surface and their subsequent periclinal divisions give rise to two unequal cells in each of these radial files (Jura et al. 2006; Karczewska et al. 2009; Włoch et al. 2009; Wilczek 2012). In the case of the intrusively growing initial, the longer of the two sister cells includes the intrusively growing tip, and maintains the status of initial, whereas the shorter one, which represents the dimensions of the cell before the intrusive growth, becomes a secondary-phloem or secondary-xylem-mother cell. An unequal periclinal division of the partially eliminated initial also results in the formation of two cells: the shorter cell preserves its initial status and remains in the initial surface, whereas the longer one (resembling the original size of the mother initial) moves away to become the secondary phloem- or secondary xylem-mother cell. In the total elimination of the initial, the whole cell loses its initial status (because it is moved away from the initials surface by the intrusively growing tip of a neighbour initial), and becomes the xylem- or phloem-mother cell. The intrusive growth and elimination, which have been described mostly as separate events, are actually two aspects of the same event (Kojs et al. 2004a, b; Jura et al. 2006; Włoch et al. 2009). In transverse view, the incidence of intrusive growth may compel the tangential walls to occupy an anticlinal position and appear as a slanted wall (Jura et al. 2006; Włoch et al. 2009; Wilczek et al. 2011). Recent investigations indicate that the main role of intrusive growth in the vascular cambium of trees pertains to relaxation of tensional strains generated during the growth of tree trunks and branches (Kojs and Rusin 2011). Intrusive growth helps in readjusting the initials according to the direction of shearing strains, and this readjustment is recorded as such in the consecutive layers of secondary phloem and secondary xylem.
None of the various models hitherto proposed for circumferential growth of the cambium, has considered the phenomenon of intrusive growth (Barlow et al. 2002; Kramer 2002), although one of these (Forest and Demongeot 2006) has referred to the elimination of the initials. The aim of the present work is to explain the mechanism of cambial initials' rearrangement through models constructed on the basis of events characteristic to the cambium and its derivative tissues in Pinus sylvestris L., taking into account the occurrence of intrusive growth and eliminations of the cambial cells. Those events were interpreted according to the recent hypothesis regarding the incidence of intrusive growth of the cambial initial along the tangential walls of a neighbouring initial and its immediate derivative.

\section{Materials and methods}

\section{Sampling and material preparation}

The study was carried out with samples of cambium, collected in October 2010 from the trunk of a 50-year-old $P$. sylvestris tree growing in a pine forest in southern Poland. The diameter of trunk at breast height was about $25 \mathrm{~cm}$. Ten blocks ( $2 \mathrm{~mm}$ long $\times 1 \mathrm{~mm}$ wide) including cambium and developing secondary xylem and phloem were collected, fixed in $2.5 \%$ glutaraldehyde, and embedded in Epon (Meek 1976). These blocks were later cut with an ultramicrotome (Tesla BS490A), each block into a long series of $3 \mu \mathrm{m}$ thin transverse (about 100 pieces) and tangential (about 30 pieces) sections and processed as described earlier (Włoch et al. 2001, 2002). The sections, glued to glass slides with Haupt adhesive (1\% gelatine in water with $2 \%$ phenol crystals and $15 \%$ glycerine), were stained with Periodic Acid Schiff Reagent (Schiff Reagent- $\mathrm{C}_{19} \mathrm{H}_{18} \mathrm{~N}_{3} \mathrm{Cl}+\mathrm{H}_{2} \mathrm{SO}_{3}$ ) and toluidine blue $\left(\mathrm{C}_{15} \mathrm{H}_{16} \mathrm{~N}_{3} \mathrm{SCl}\right)$, and finally mounted in Euparal (Karczewska et al. 2009).

The series of successive sections, presenting the slanted walls in radial files either in the cambial zone or in the secondary xylem and phloem carrying records of rearrangement of cambial cells, were photographed with an Olympus camera. Reconstructions of cells were made on the basis of these photographs, using Corel Draw X3 software, to show new adjustments and the consequent rearrangement of growing cells.

Modelling of the rearrangement of cambial initials due to intrusive growth

On the basis of the rearrangement of initial cells, displayed as slanted walls in radial cell files, certain models have been developed to explain the most probable course of events at different points of time. For the models proposed, 
we assumed that the cambial cells in a cross section are rectangles (with a longer tangential wall and shorter radial walls), having equally and evenly thickened radial and tangential walls. The models are based on the following assumptions:

1. The radial walls of cambial cells expand by means of symplastic growth;

2. The radial growth involving addition of new cell layers occurs with different intensity on the phloem and xylem sides, resulting in differential radial increment (in proportion of 1:3 respectively);

3. Occurrence of periclinal divisions in neighbouring radial files is non-synchronous;

4. The initial grows intrusively along the tangential walls of the neighbouring cells.

5. Each radial file contains one initial that forms part of the initial surface.

\section{Results}

New concept of intrusive growth of cambial initials and the formation of slanted walls

The $P$. sylvestris trunk examined had a right-hand spiral grain in the wood. On transverse sections of the cambium, we observed numerous slanted cell walls representing the tips of intrusively growing cambial initials and indicating that rapid rearrangement of cambial initials was in progress (Fig. 1a-f). The old concept of the cambial-cell rearrangement would consider these situations as separate events of intrusive growth (between radial walls of adjacent initials) (Fig. 1a-c) and cell elimination (Fig. 1d-f). The new concept of the cambial initials' rearrangement has explained the appearance of slanted cell walls in transverse sections as an outcome of the intrusive growth along tangential walls and the cell elimination, considering these two events as different aspects of the same process. This process may result in the formation of a new radial file, initially visible in transverse view as the characteristic triangular or rhomboidal figure (Fig. 1a-c), or in the elimination of a radial file (Fig. 1d-f).

Figure $1 \mathrm{~g}-\mathrm{i}$ presents certain locations on transverse sections of the wood, where numerous slanted cell walls are visible, indicating the occurrence of intrusive growth on tips of the cambial initials, at the time when the concerned layers of wood cells were formed. Analysis of the radial files' arrangement revealed that the slanted cell walls appeared in the case of both (i) the eliminating and (ii) the newly emerging radial files. The total number of the radial files examined did not change during the time period involved in the deposition of those wood layers, despite a significant change in the arrangement of the files.

Analysis of the rearrangement of the cambial initials, carried out with a series of 75 semi-thin transverse sections, obtained from a sample of $263 \mu \mathrm{m}$ length in axial direction (Fig. 2), revealed that we cannot distinguish on the basis of single sections only whether the radial file examined has been eliminated or is actually growing intrusively. Therefore tangential reconstructions of cells from the xylem, cambium and phloem regions were made. Superimposing the reconstructions of the xylem and phloem layers revealed that the arrangement of the radial walls of cells in these layers was precisely the same. Also, overlaying the reconstructions of cambial cell layers versus phloem cell layers, and cambial cell layers versus xylem cell layers revealed that the initials of radial files \#2 and 3 had changed their positions in an $\mathrm{S}$ (right) direction, whereas the initials of radial files 1 and 4 hardly changed their position during this time span. Consequent upon this rearrangement, the initial of radial file 2 was transferred to radial file 3 , and simultaneously, the initial cell of radial file 3 was partly eliminated (Fig. 2ii). Careful examination of transverse sections [(Fig. $2 \mathrm{i}(\mathrm{a}-\mathrm{h})]$ has revealed that the initial cell of radial file 3 had been eliminated, as this radial file was not visible in the cambium in sections $\mathrm{f}-\mathrm{h}$. The tip of this initial is still visible in a 4-celled intruding radial file in the cambium [Fig. 2i (e)]. Interestingly, the tip of this partially eliminated initial experienced slight intrusive growth after the process of elimination was over; this appeared in sections $d$ and e as the slanted walls of the 4-celled intruding radial file. Thus, it could be deduced from the above that the elimination of this initial had taken place before the four layers of its immediate derivatives were produced.

If we analyze the arrangement of radial files only in a single section, e.g. in Fig. $2 \mathrm{i}$ (f) of this series, we would interpret it as a typical example of elimination of radial file 2 , whereas a detailed analysis of the series of transverse sections has brought out that in fact it was the radial file \#3 that underwent elimination. The initial of radial file 2 did not eliminate, but only moved to the right.

Models for rearrangement of the fusiform initials

The model presented in Fig. 3 is based on a detailed analysis of mutual contacts of cells in three (two already existing and one newly emerging) radial files, as seen at four points of time, showing the gradual elimination of an initial of radial file \#1 by an intrusively growing initial in the newly emerging file. In the area where intrusive growth is in progress, the process of gradual shifting of periclinal walls of some fusiform initials to a radial position becomes visible in the form of slanted walls. The intrusively growing fusiform initial intrudes between the tangential 
Fig. 1 Transverse sections from different positions of cambium (a-f) and wood (g-i) of $P$. sylvestris, showing the intrusive growth of the cambial initial, marked with an arrow (in $\mathbf{a}, \mathbf{b}$ and $\mathbf{c}$ ), and the elimination of radial file 2 in (d) and radial file 3 (in e and f). Rearrangement of cambial initials as recorded in the wood can be seen in transverse sections ( $\mathbf{g}, \mathbf{h}$ and $\mathbf{i})$ obtained from different levels and locations in the wood sample. Time-vector indicates the sequence of consecutively deposited layers of wood, from the oldest to the newest layer. The dashed lines indicate the arrangement of radial files. Eliminated files are marked by the termination of dashed lines. Intrusion of new radial files is marked with dotted lines. The split of one dashed line into two indicates the occurrence of anticlinal division (i)

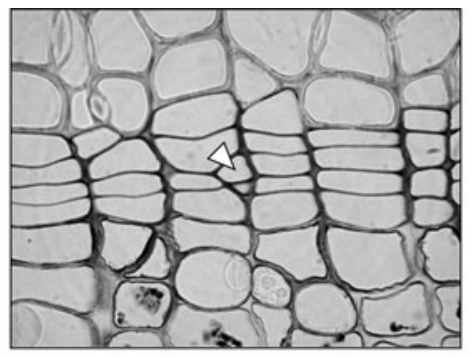

A
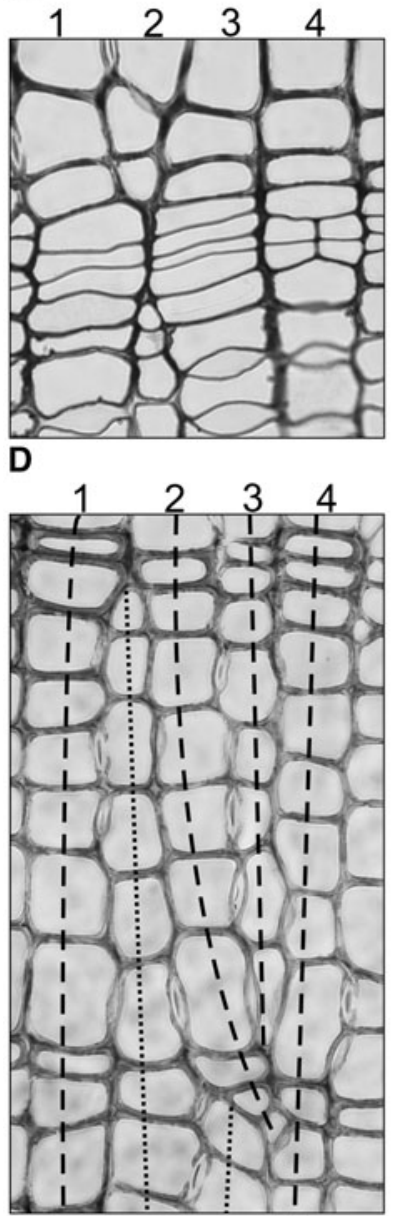

$\mathbf{G}$

walls of the neighbouring initial and its closest derivative $\left(t_{1}\right)$, which, with the passage of time $\left(t_{2}-t_{3}\right)$, leads to the development of slants, similar to those shown in Fig. 1a-c. The fixed position of corresponding filled circles placed on the contiguous tangential-to-radial transforming walls $\left(x-x^{\prime}, y-y^{\prime}, z-z^{\prime}\right)$ indicates that the intrusive growth takes place on longitudinal edges of the cell, resulting in intrusion of the elongating cell tip along the tangential walls of the adjacent initial and its closest derivative. This rearrangement of cells is concurrent with the radial expansion of cell walls by symplastic growth and the occurrence of periclinal divisions of the cells so enlarged, and causes no increase in the cambial circumference.

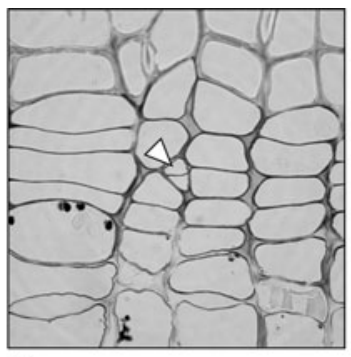

B

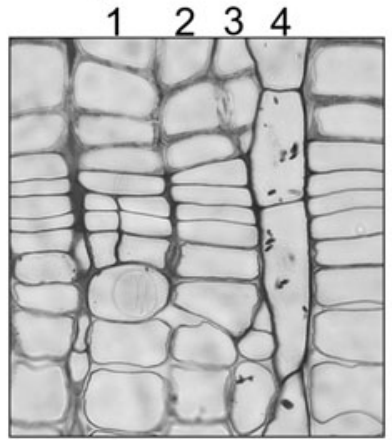

E

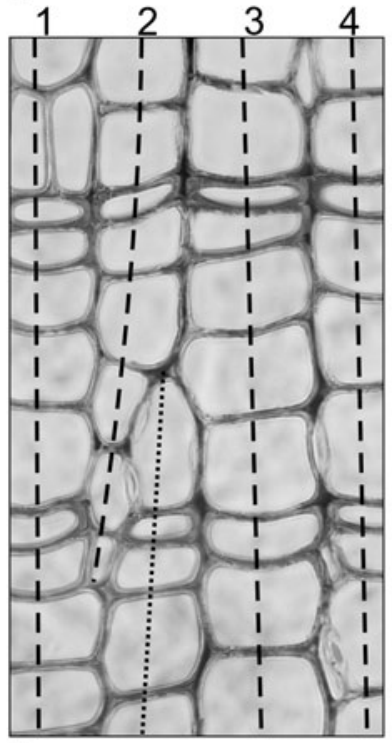

H

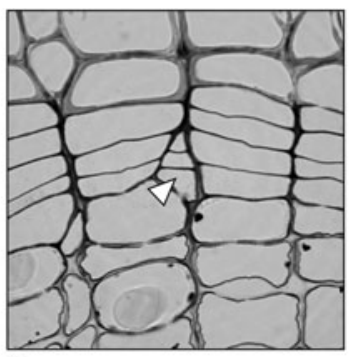

C

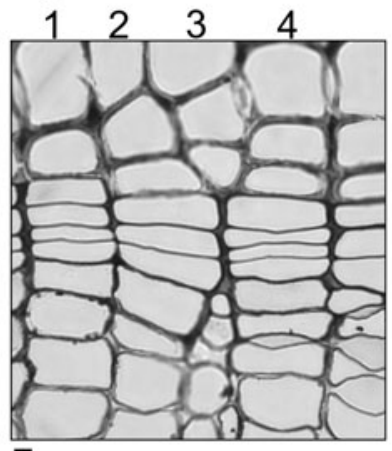

$\mathbf{F}$

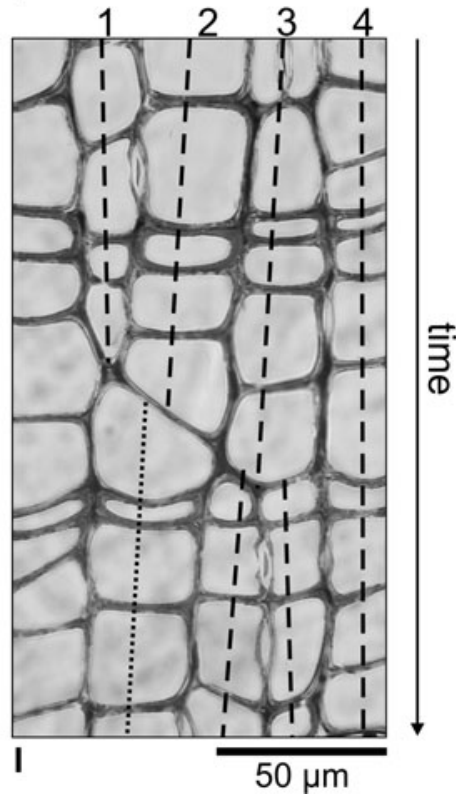

Three radial files (two already existing and one newly emerging cell files) chosen to demonstrate the rearrangement of cambial initials due to their apical intrusive growth, as detected at six points over a given time span of radial growth of the stem, are presented in Fig. 4. Both the initial cells and their derivatives grow in a radial direction in a coordinated way by symplastic growth, i.e. the radial walls of adjacent cells in neighbouring radial files grow together and these growing cells do not change their contacts. Thus cells in neighbouring files grow simultaneously and this is why the lines marked according to location of edges between tangential and radial walls of the given three radial files do not cross each other. The rearrangement 

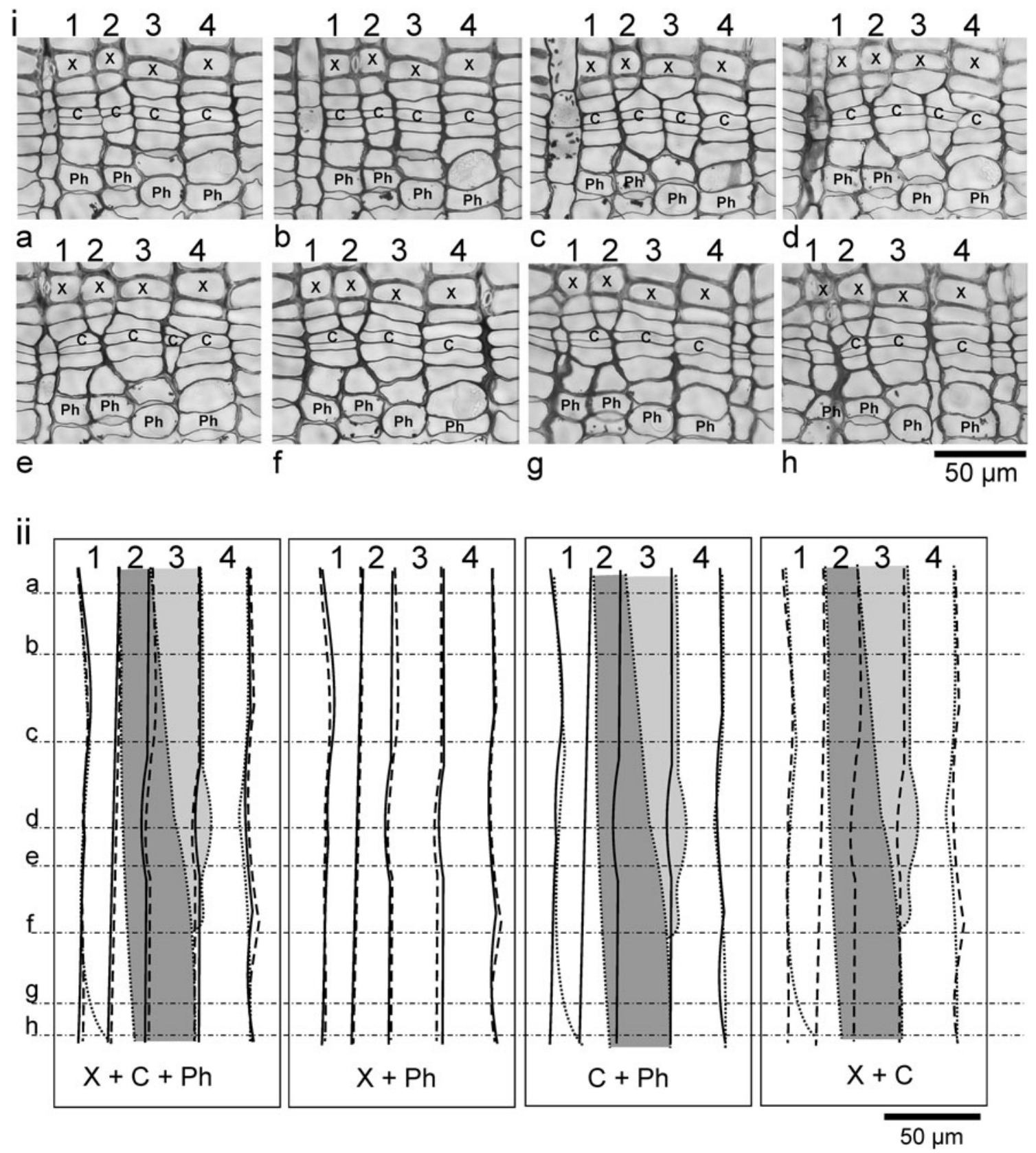

Fig. 2 Rearrangement of cambial initials in P. sylvestris stem. Section (i) includes eight views chosen from a long series of 75 transverse sections covering a distance of $263 \mu \mathrm{m}$ in axial direction. In the tangential reconstructions of section (ii), $1,2,3$ and 4 are the serial numbers of radial files examined, while $a-h$ are different positions along the given axial length of the stem axis from where the

caused no increment of cambial circumference, as the total tangential width of the presented group of three radial files did not change. At the time point $t_{0}$, the tip of the intrusively growing fusiform initial of radial file II is seen protruding between the initial cell and its derivative secondary-phloem-mother cells of radial file I. The views taken at the other points of time $\left(t_{1}-t_{5}\right)$ present the consecutive changes in the cell arrangement in those radial selected eight transverse sections were obtained. The four tangential views of (ii) present the superimposed reconstructions of cells of the four radial files in different combinations. Letters $X, C$ and $P h$ indicate the cells of secondary xylem, vascular cambium and secondary phloem, and are drawn by dashed line, dotted line and continuous line, respectively

files, which occur together with the concurrent symplastic radial enlargement as well as the periclinal divisions of the cells concerned.

Figure 5 analyzes the varied pace of intrusive growth in circumferential direction, between tangential walls of an initial cell in the neighbouring radial file and its immediate derivative. The intrusive growth in circumferential direction takes place in conjunction with a significant 


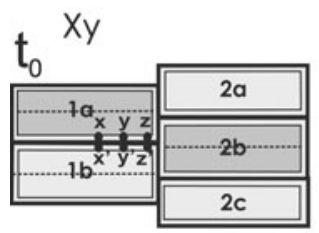

$\mathrm{Ph}$

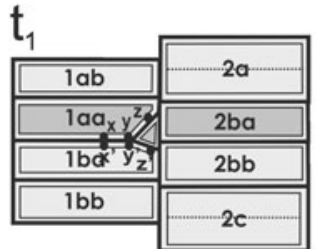

$t_{2}$
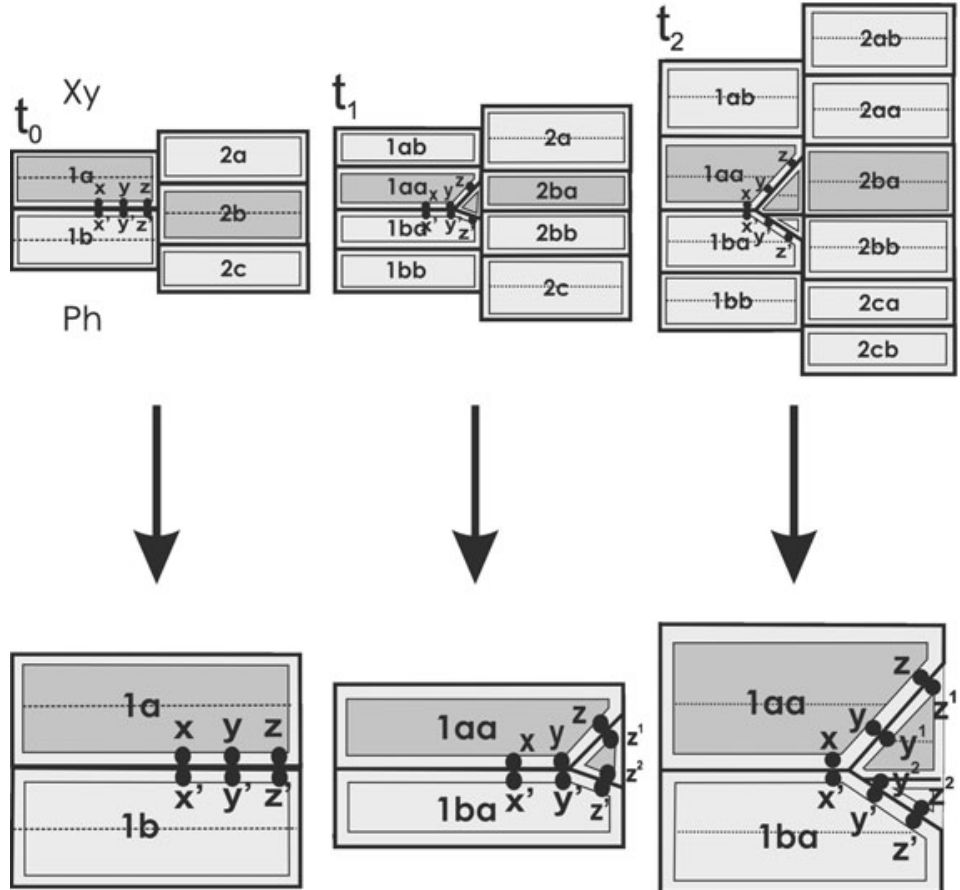

Fig. 3 A model of intrusive growth of fusiform initial covering situations at four time points $\left(t_{0}-t_{3}\right)$ : enlarged views of the intrusively growing initial and the eliminating initial and their closest derivatives are presented below arrows. At the time point $t_{0}$, two radial files ( 1 and 2) are considered. At $t_{1}-t_{3}$ in addition to these two radial files a third one also becomes visible, which has been derived from the initial growing intrusively between the neighbouring initial and its closest derivative in radial file 1 . The cells marked by dark grey (initials) and bright grey (derivatives) undergo periclinal divisions (dotted line) during the time span involved. Black circles marked with letters $x y z$ and $x^{\prime} y^{\prime} z^{\prime}$ and placed in pairs on opposite cell walls, which are transforming their orientation from tangential to slanted, exhibit constant cell-wall contacts. Letters ' $a$ ' and ' $b$ ' correspond with the

intrusive growth in axial direction, but this cannot be observed on a single transverse section, and hence is not presented in this model. When the intrusive growth is slow, the angle between slant and radial walls is small (Fig. 5a); as shown also in the actual transverse section in Fig. 1g. A rapid cell growth gives rise to a large angle between slant and radial cell walls, with the same intensity of symplastic radial growth (Fig. 5b). A similar example is shown in Fig. 1h.

The arrangement of slanted walls, as observed in transverse sections, depends on the extent of intrusive growth in circumferential direction, as presented in Fig. 6, depicting three different models for identical pace of intrusive growth (the angles between slants and radial cell

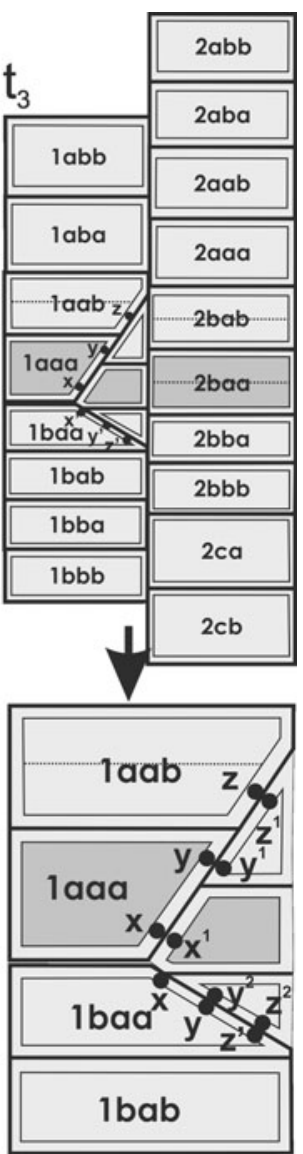

occurrence of successive periclinal divisions; their combinations thus indicate the sequence of derivatives formation. The fusiform cells in the first point of time are numbered in each radial file, from xylem to phloem as $a, b, c$, following the number of radial file $(1,2)$. The next letters $(a$ and $b$ ) indicate the sequence of periclinal divisions: for instance, periclinal division of cell $1 a$ results in the formation of two cell; $1 a a$, which stays on the initial surface, and cell $1 a b$, which becomes a xylem-mother-cell. Similarly, periclinal division of cell $l a b$ forms two cells: $1 a b a$ (closer to initial surface) and $l a b b$ (closer to mature xylem). The cells formed by periclinal divisions, which are closer to initial surface, are marked by addition of letter ' $a$ ' at the end of previous label, whereas those farther from initial surface are marked by addition of letter ' $b$ ' (on time points $t_{1}-t_{3}$ )

walls being equal). If the extent of intrusive growth is limited to half of the neighbouring initial's width, after the cessation of intrusive growth the cell walls transform from slanted to radial ones, and a new additional radial file is formed (Fig. 6i). If the extent of intrusive growth is large enough, the intrusively growing cell may eliminate the whole of the neighbouring initial (Fig. 6ii). In this case, one radial file replaces another radial file. If the initial grows intrusively in one direction, it results in a triangular arrangement of slanted walls, similar to those shown in Fig. 1b, c. However, if the intrusive growth occurs in both (left and right) directions, the slanted walls form a rhomboidal figure, similar to one presented in Fig. 1a. In this case a new, an additional radial file is formed. 
The next three models (Figs. 7, 8, 9) analyze different situations of the cambial initial rearrangement, both in the tangential and transverse views. They establish the relationship between intrusive growth and elimination of initials, as per the recent hypothesis of intrusive growth occurring between tangential walls of neighbouring initial and its immediate derivative. Moreover, these models exhibit the simultaneous occurrence of intrusive growth in an axial direction as well as a circumferential direction, a feature not included in the previous models.

Figure 7 presents a model of the rearrangement of cambial initials, comparing the transverse and tangential views. Three fusiform cells $(1,2,3)$ are shown before the occurrence of intrusive growth (Fig. 7a) and after the occurrence of intrusive growth of initial \#3 (Fig. 7b, c, d). The extent of intrusive growth is varied. It eliminates either a part of initial \#2 (Fig. 7b), corresponding with the situation presented in Fig. 6 (i), or the whole initial \# 2 (Fig. 7c), corresponding with the situation presented in Fig. 6 (ii), or parts of initials 1 and 2 (Fig. 7d), corresponding with the situation presented on Fig. 6 (iii). The model reveals that together with the occurrence of intrusive growth in circumferential direction, which can be seen in single transverse section (as in Figs. 5, 6), there also occurs intrusive growth in axial direction, which can be seen in tangential sections.

In Fig. 8, scheme 'a' shows the fusiform cells before the occurrence of intrusive growth, whereas schemes ' $b$ ' and 'c' exhibit fusiform initials of the same radial files, as in scheme ' $a$ ', but after the occurrence of intrusive growth. It can be seen that tips of the growing initials (cell \# 1 in scheme $b$ and cells \#1 \& 2 in scheme c) partially eliminated the initial \#3. There are also models of transverse sections showing the situation at the two levels marked on tangential sections by lines $X$ and $Y$. The models for plane $X$ exhibit the rearrangement commonly described as 'total elimination', whereas those for plane $Y$ demonstrate what is described as 'partial elimination', i.e. narrowing of the radial file. These models reveal that the event of cell elimination, shown by single transverse sections, is actually a result of intrusive growth of the neighbouring initial or initials. Similar examples of eliminations of radial files are shown in the actual transverse sections in Fig. 1d, e \& f. The main feature in which this model differs from the previous one (Fig. 7) is the location of transverse sections on the tangential view in relation to growing tip of the initial. In Fig. 7, transverse section (a) presents the view of a location above the tip of the growing initial \#3. In this situation the axial intrusive growth of the initial resulted in the formation of a new, intruded radial file. In Fig. 8, transverse section (a) has been made at a different level, which includes the tips of initials (\#1 and 2) that were supposed to grow; so these cells were visible even before the occurrence of intrusive growth. This condition demonstrates that the axially growing initials would look and be described in transverse sections as the circumferential expansion of these initials, causing partial $(Y)$ or total $(X)$ elimination of radial file \#3. Thus the analysis of a single transverse section $(X)$ would be described just as the "total elimination", though it is only a "partial elimination" of the tip of the initial \#3.

Figure 9 presents a model developed to emphasise the location of the growing tip of a fusiform initial in relation to positions along the plant axis from where the transverse sections have been obtained. This model also exhibits rearrangement of cambial initials in tangential view, and compares it with three views seen in transverse sections (Fig. 9 iii) taken from positions indicated on Fig. 9 i, ii with lines $X, Y$ and $\mathrm{Z}$. The first of these transverse sections $(X)$ presents the situation described commonly as elimination of radial file (Fig. 1d, e, f). Similar examples are shown in Fig. 1d, e, f. In the next two transverse sections ( $Y$ and $Z$ ), elimination of radial file is located next to the intrusively growing tip of cell (1). Examples similar to transverse section $Z$ have been presented in Fig. 1a, b, c. If we observe the same cells in superposition of tangential sections as in Fig. $9[\mathrm{i}(\mathrm{a}+\mathrm{b})]$ and their enlarged view in Fig. 9(ii), we would describe it as intrusive growth of initials 1 and 2. So, depending on the plane and the position from where the section has been obtained, the same rearrangement would be described as an outcome of elimination of one initial or intrusive growth of the other. This clearly shows that elimination of an initial is a result of intrusive growth of the neighbouring initials.

\section{Discussion}

Intrusive growth and elimination of cambial initials

Cumbie (1963) highlighted the significance of longitudinal elongation of sister fusiform initials produced by the pseudotransverse anticlinal divisions in the non-storeyed cambium. Apical intrusive growth of these initials was considered to be an important mechanism of increase in the cambial circumference (Hejnowicz and Branski 1966; Iqbal 1990; Larson 1994; Evert 2006). The exact localization of intrusive growth of the fusiform cambial initials is still a subject of debate. Hejnowicz and Zagórska-Marek (1974) identified occurrence of intrusive growth at radial edges of the cambial initials and suggested that the cell-tip intrusion takes place between radial walls of the neighbouring initials (Larson 1994). If the intrusive growth of the initials increases the cambial circumference, obviously it has to occur between the radial walls of adjacent initials. Thus all those authors who consider intrusive growth as the main 

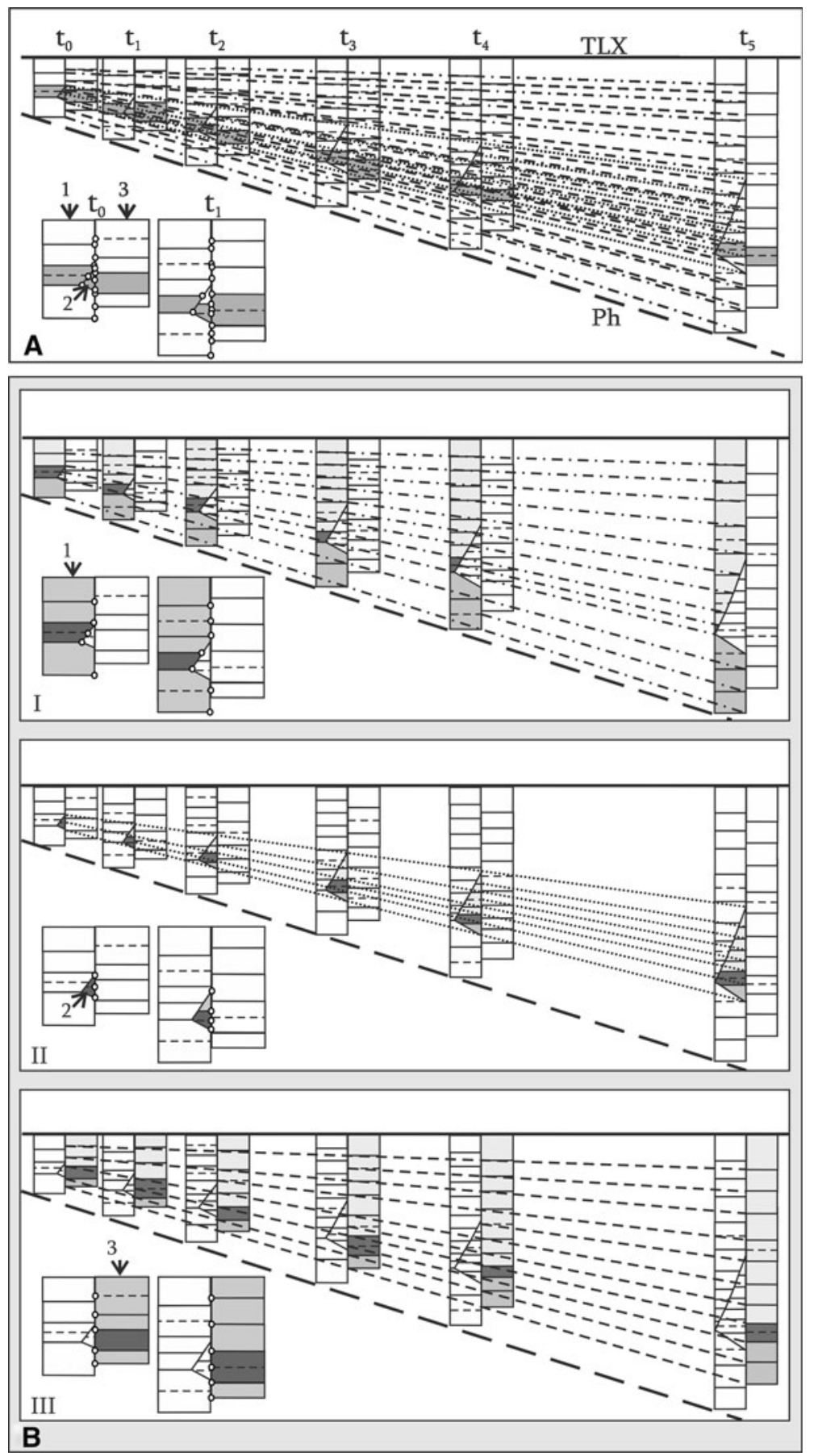

mechanism of circumferential enlargement of the cambial cylinder, in principle assume that intrusive growth occurs along radial walls, even if they do not confess it categorically.

The intensity of anticlinal divisions in the non-storeyed cambia, followed by intrusive growth of the initials produced, was found to be much higher than actually required for due increment of the cambial circumference; this excess cell production was supposed to be compensated through elimination of the initials (Bannan 1950, 1957, 1960a, b; Evert 1961; Hejnowicz 1961; Hejnowicz and Brański 1966; Cumbie 1967; Srivastava 1973; Romberger et al. 1993; Larson 1994). Such a phenomenon has not been observed in storeyed cambia, and it has yet to be explained why the excessive generation of initials is confined to the non-storeyed cambia alone.

Elimination of extra initials is believed to occur through their decline (Hejnowicz and Brański (1966), their 
4 Fig. 4 A model of radial growth of three radial files (1-3) of fusiform cambial cells (files \# 1 and 3 already exist, while file \# 2 is emerging due to intrusive growth of an initial), considered in transverse plain: A single transverse section was seen at six time points $\left(t_{0}-t_{5}\right)$. The initial cell of radial file 2 is currently growing intrusively. The thick, continuous horizontal line represents the border between the current annual ring and the last layer of the previous annual ring (terminal late xylem) marked as TLX, as a reference surface, which is in a stable position during the radial growth. The arrangement of cambial cells in three radial files at all the six time points indicates the same position of TLX. On the lower side, the thick dashed line represents the border between the last layer of the mature phloem derived in the previous year (marked as $P h$ ) and the current year increment of the phloem. This border is pushed outward by radial growth of stem due to addition of new derivatives on the inner side of cambium through repeated periclinal divisions. Periclinal divisions of cambial cells are marked with horizontal, dashed lines. A In the left bottom corner of the scheme (A), two points of time are enlarged and circles have been marked indicating cell wall edges between tangential and radial walls (also periclinal divisions) between the three radial files analyzed. In the upper scheme the corresponding edges have been connected in radial files 1-3 between all six points of time with lines: 1-dashed and dotted, 2-dotted and 3-dashed lines. The initials are marked in grey. B Lines drawn to mark the location of edges between tangential and radial cell walls in each of the radial files 1,2 and 3 are shown in three separate drawings (I, II, III respectively). In the left bottom corner of the schemes situations at two points of time $\left(t_{0}\right.$ and $\left.t_{1}\right)$ are shown in enlarged view, marking the cell wall edges between tangential and radial walls (also the periclinal divisions) with small circles. The radial file analyzed is marked in grey shades; the phloem-mother cells and xylem-mother cells are marked in medium grey and bright grey respectively, whereas the initials are shown in dark grey. The changes in location of cell wall edges between the tangential and radial walls occurring in radial files 1,2 and 3 are shown in illustrations I, II and III of section B, respectively

differentiation into the phloem or xylem element (Bannan 1952; Cumbie 1967; Larson 1994), or by the domination of neighbouring initials (Forest and Demongeot 2006). Interestingly, none of the above explanations takes into account the occurrence of intrusive growth of cambial initials. In the words of Forest and Demongeot (2006), elimination stems from the progressive domination of cells of one file over those of the other, causing decrease in perimeters of the latter's cells. These authors regarded this domination as being caused by the contact strength exerted by the neighbouring files as a consequence of competition. Such an assumption, however, is not consistent with the recorded observations, given that the cambium is always in a state of considerable tensile stress in tangential direction (Hejnowicz 1980; Kojs and Rusin 2011; Kwiatkowska and Nakielski 2011).

The above explanations suggest that intrusive growth should occur when the cambium is tangentially stretched, i.e. under tensile stress (Romberger et al. 1993; Kwiatkowska and Nakielski 2011), whereas a precise mechanism of elimination has not yet been determined. It is difficult to explain the occurrence of competition for space between the cambial initials, as postulated by Forest and Demongeot

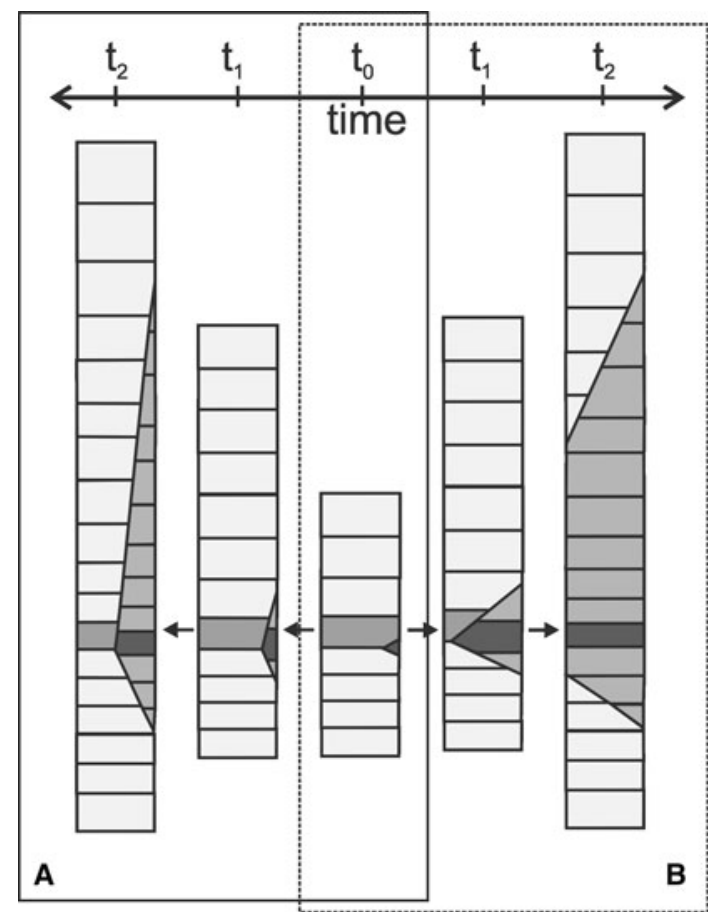

Fig. 5 Models of intrusive growth of fusiform initials in circumferential direction occurring at different pace over a time span $\left(t_{0}-t_{2}\right)$ as seen in a transverse view. The middle drawing $\left(t_{0}\right)$ shows the cell pattern at the beginning of intrusive growth. Toward its left is the model $(A)$ of slow growth of the initial whereas to its right is the model $(B)$ of rapid growth during the same time span and in conjunction with the same rate of the symplastic radial growth. The initials are marked with darker grey than their derivatives. Cells in the radial file marked with bright grey display a case of elimination, whereas those marked with middle grey are the derivatives of the intrusively growing (dark grey) initial

(2006), when the tissue is tangentially stretched. On the contrary, such a competition may be expected when the tissue would be locally compressed in tangential direction, a situation not yet reported about the cambium. The above interpretation also leads to the assumption that intrusive growth and elimination do not occur together, in the same area of the cambium, as they would be an outcome of contradictory mechanical conditions. However, observations confirm that intrusive growth occurs commonly in the neighbourhood of eliminations, as reviewed by Larson (1994). Long back, Nägeli (1864) mentioned that increment of one radial file explains the "shortening and death" of the adjacent file, a condition later described as elimination of initials. Bannan (1957) also enunciated that following the pseudotransverse anticlinal division, one of the sister initials would predominantly be eliminated, whereas the other one would grow intrusively.

Kojs et al. (2004a, b) regarded the intrusive growth as occurring on longitudinal (tangential) edges, thus suggesting the cell intrusion between tangential walls of the neighbouring initial and its immediate derivative. A similar 


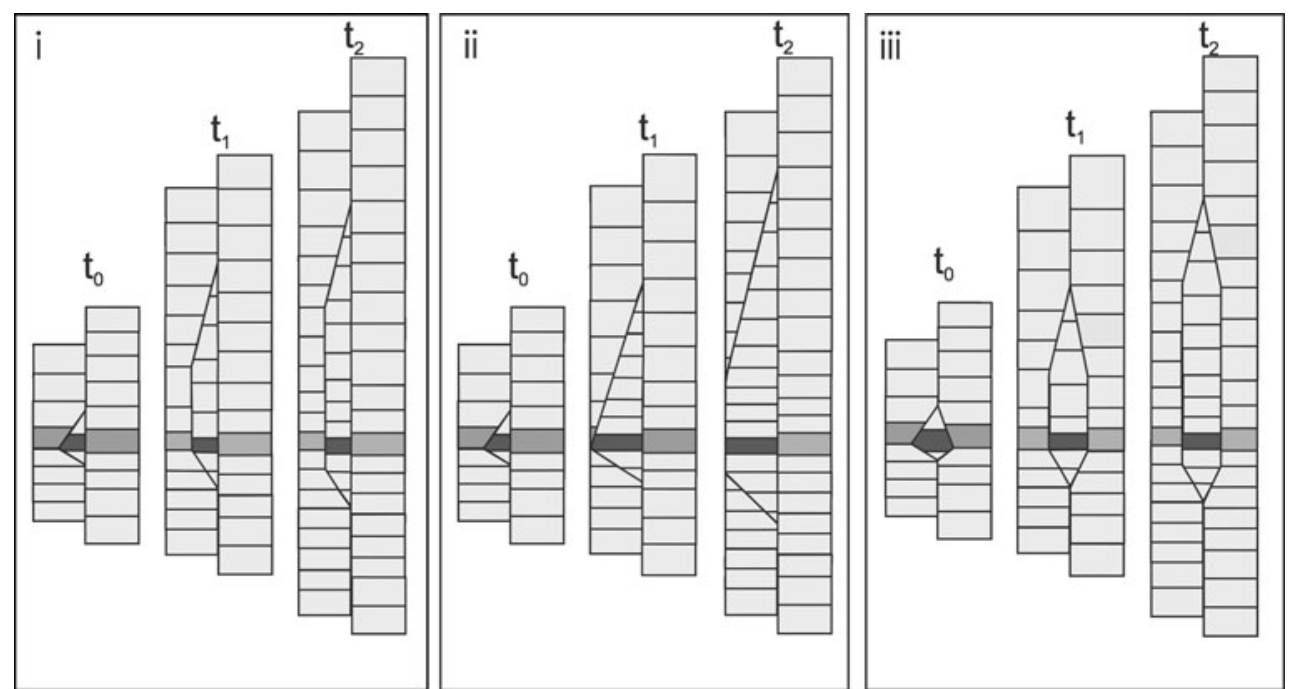

Fig. 6 A model of three different extents of intrusive growth in circumferential direction over a given time span $\left(t_{0}-t_{2}\right)$, as observed in transverse section. The pattern of the slanted cell walls depends on layers of cells deposited during the progress of intrusive growth. In diagram (1), intrusive growth occurs in one (left) direction, initiating the triangular arrangement of slants (at $t_{0}$ ), and ceases when the growing cell has reached the middle of the partly eliminated radial file, thus causing the formation of a new radial file $\left(t_{1}-t_{2}\right)$. In diagram (2), intrusive growth occurs in one direction (left) resulting in

situation was described earlier for tumorous cambia (Włoch 1976; Larson 1994; Włoch et al. 2001). Later it was generalised as a common mechanism of intrusive growth of the cambial initials (Kojs et al. 2004a, b; Jura et al. 2006; Karczewska et al. 2009; Włoch et al. 2009). This hypothesis of the occurrence of intrusive growth along tangential walls explains why intrusive growth occurs always in conjunction with eliminations. This also confirms that neither the elimination nor the intrusive growth has an influence on cambial circumference (Jura et al. 2006; Włoch et al. 2009; Wilczek et al. 2011). The occurrence of intrusive growth in one initial means an equal elimination of the adjacent initial, thus proving that the two events are complementry.

The rearrangement of cambial initials can hardly be understood by examining a single transverse or tangential section. Analysis of long series of transverse sections is similar to data collection from tomography and allows for precise reconstruction of cells' arrangement. The models presented in this paper allow for taking into consideration the occurrence of intrusive growth in the modelling for symplastic growth in radial direction. The initials, after completion of intrusive growth, continue their growth by symplastic mode only. New observations have revealed that the growing tips of the cambial initials intrude between the tangential walls of the neighbour initials and their immediate derivatives and, therefore, have no influence on the cambial-circumference enlargement. triangular arrangement of slants $\left(t_{0}-t_{1}\right)$, and ceases when the intrusively growing cell has reached the next radial file, thus leading to the elimination of one radial file through consistent narrowing of its initial (at $t_{2}$ ). In diagram (3), the cell grows intrusively in two (left and right) directions, resulting in a rhomboidal figure marked with slanted walls of newly formed radial file with intrusively growing initial (at $t_{0}$ ), ultimately causing a partial elimination of two neighbouring radial files (at $t_{2}$ )

Anticlinal divisions versus circumferential growth of cambium

Anticlinal divisions increase the number of cambial initials. The percentage of added fusiform cells remains considerably higher during the first few years of cambial activity, when the radius of the cambial cylinder is very little; it later decreases markedly when the stem grows thicker (Bailey 1923; Butterfield 1972; Iqbal 1994; Kojs et al. 2004b). In an old, thick stem the overall number of fusiform initials added to the cambial circumference is very small, although the anticlinal divisions are more frequent. Predominantly, after the anticlinal division of a fusiform initial, one of the resultant sister initials is eliminated (Bannan 1950; Evert 1961; Srivastava 1973; Cumbie 1967; Lim and Soh 1997a, b).

The linear diagram of tracheids' radial files from the secondary xylem of Chamaecyparis nootkatensis (Bannan 1950) revealed that 16 fusiform initials identified on the circumference of cambial cylinder at the $6 \mathrm{~mm}$ radius divided anticlinally 71 times during the radial increment of $2 \mathrm{~mm}$ (from 6 to $8 \mathrm{~mm}$ radius), thus adding 71 new cells to the already existing 16 cells and making a total of 87 initials. However, over the radius of $8 \mathrm{~mm}$, the chosen segment possessed only 26 fusiform initials instead of 87 . This means that only 10 fusiform initials $(14 \%)$ were added, and 61 of them ( $86 \%$ ) eliminated. The number of anticlinal divisions was 7 times higher than the actual 
Fig. 7 A model to compare a given situation of cell arrangement in tangential (1) and transverse (2) sections: The horizontal, dashed line drawn on tangential sections indicates the position of transverse sections presented below ( $b$, $c$ and $d$ ). The horizontal, dotted lines drawn on transverse sections $(b, c, d)$ correspond to the positions of tangential sections $(a, b, c$ and $d$, respectively) presented above a) A tangential view showing two radial files (1-2) at the position indicated by the dotted line, which is marked as ' $a$ ' on all the three transverse sections $(b, c \& d)$, indicates the situation prior to the occurrence of intrusive growth. Radial file \#3 of this drawing is not visible in the transverse view, because its upper end is still below the dashed, horizontal line $b-$ d) Three examples of cell rearrangement, showing varied extent of intrusive growth of the initial of radial file \#3, both in tangential (above) and transverse (below) views. The initial \#3 and its derivatives are marked with dotted line $a+b$, $a+c$ and $a+d$ are the superpositions of the respective tangential views and reveal the occurrence of intrusive growth of initial \# 3
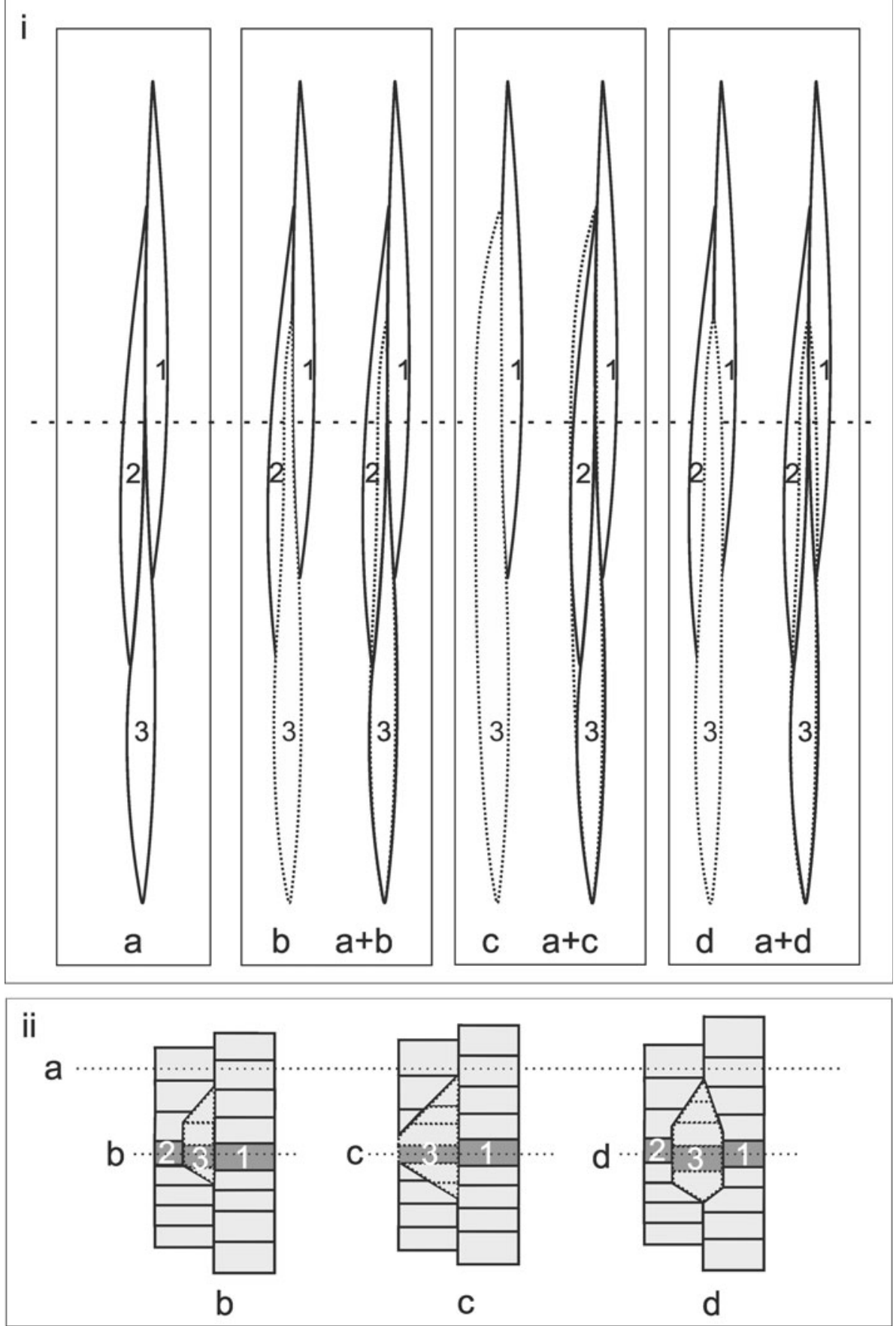

requirement for due increase in the cambial circumference. Analysis of the same diagram at a different magnitude of cambial radius (between 3 and $6 \mathrm{~mm}$ ) revealed that despite a very high number (83) of anticlinal divisions occurring during the time span involved with this radial increment, the number of fusiform initials in the given sector had not changed at all. There were 16 initials both at the beginning and at the end of this $3 \mathrm{~mm}$ radial increment (Bannan 1950). If anticlinal divisions occur only to increase the number of initials in the cambial circumference, it is incredible that all the added initials were eliminated in this instance. It showed, however, that anticlinal divisions took almost no part in increasing the cambial circumference.

In 1964, Bannan's study of Pseudotsuga menziensii wood, sampled from a trunk of 11-inch diameter, brought out a curious example of excess anticlinal divisions. By examining $8 \mathrm{~mm}$ of radial increment, caused by cambial activity in 4 years, he traced the history of anticlinal divisions and eliminations of 10 fusiform initials. The 10 initials divided anticlinally 18 times, adding 18 new initials. However, after the last annual increment examined, there were only 11 fusiform initials in total (Bannan 1964). 

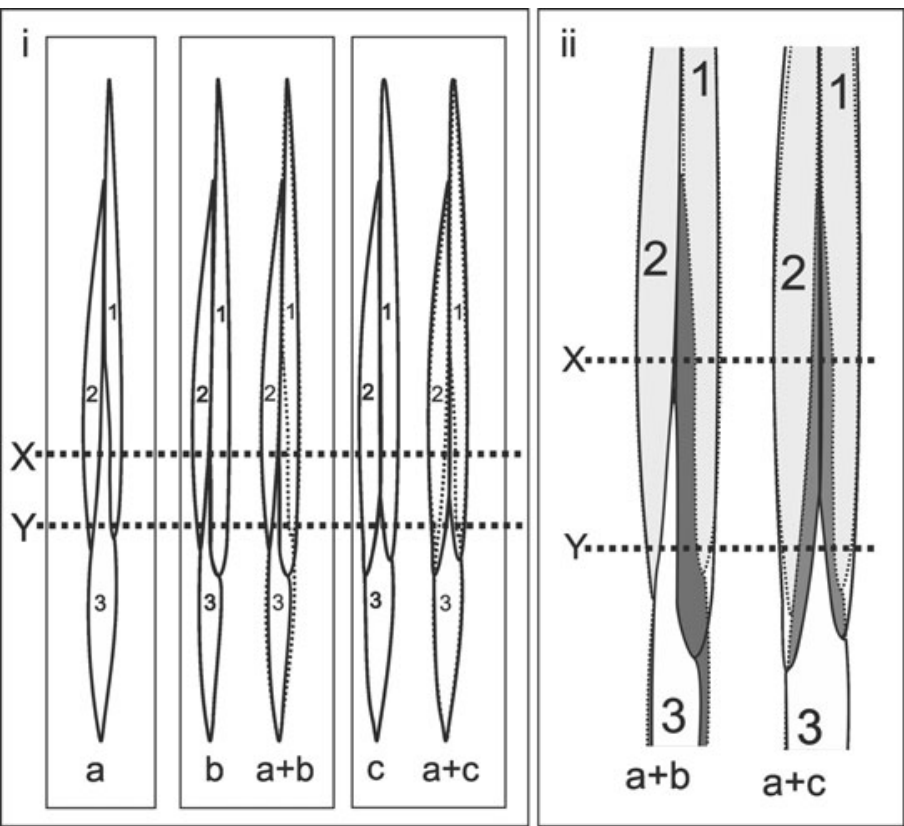
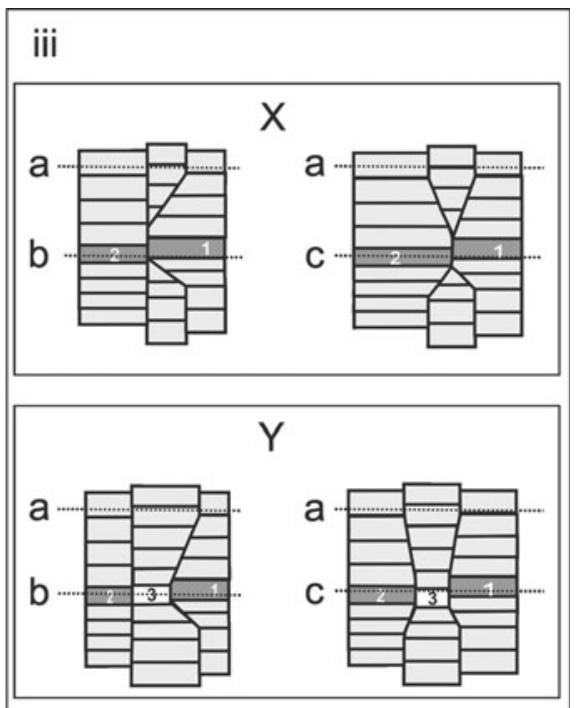

Fig. 8 A model comparing the arrangement of three radial files of cambial cells $(1-3)$ observed in tangential and transverse sections: On the left, the arrangement of cells has been shown in tangential sections before the occurrence $(a)$ and after the occurrence ( $b$ and $c$ ) of intrusive growth i) Superposition $(a+b)$ shows intrusive growth of initial \#1, resulting in a partial elimination of initial \#3, whereas superposition $(a+c)$ demonstrates the concomitant intrusive growth of initials \#1 and \#2, again causing a partial elimination of initial \#3 ii) The schemes illustrate an enlarged view of superpositions $a+b$ and $\mathrm{a}+c$ (i), showing the cell overlap by intrusive growth. The eliminated part of initial \#3 is marked in dark

This means that 17 newly added initials were eliminated (94.4\%) and only 1 initial (5.6\%) was added to the cambial circumference.

Such examples are numerous in the literature. Evert (1961), for instance, examined the wood of pear tree trunk in 7 consecutive annual increments. During this time span, 20 fusiform initials divided anticlinally 35 times, thus forming 35 new initials altogether. Of these, seven cells (i.e. $20 \%$ ) transformed into rays, 23 cells (i.e. $65.7 \%$ ) were eliminated and only 5 cells (i.e. $14.3 \%$ ) maintained the fusiform initial status. Thus, the number of eliminations was more than 4 times higher than the number of actually added initials. Srivastava (1973) proposed a model illustrating the frequency of anticlinal divisions over a 50-year span of cambial activity, assuming that the tree-trunk diameter grew from 20 to $200 \mathrm{~cm}$ (10 times increase). In his model, each fusiform initial should divide 9 times, forming 10 fusiform initials altogether, in order to meet the actual requirement of the expanding cambial circumference. He observed that the actual number of anticlinal divisions in the trunk was much higher (26 divisions). From the newly added 26 fusiform initials, 17 initials (i.e. $65.4 \%$ ) were eliminated and only 10 (i.e. $38.5 \%$ ) grey. The cells \#1 and 2, before the occurrence of intrusive growth, are shown in bright grey. The tips of these intrusively growing initials have also eliminated slightly the small parts of neighbouring radial files outside the area originally covered by the initials 1,2 and 3. The initial \#3, partly eliminated but still appearing on the initial surface, is shown as a white cell iii) The models illustrate reconstructions of transverse sections made at positions marked with dotted horizontal lines $X$ and $Y$ drawn on tangential sections (i, ii). Dotted lines $(a, b$, $c$ ) indicate the plane in which tangential sections $a, b$ and $c$ respectively, have been made

contributed to the cambial-circumference increment. Several other studies (Cumbie 1967; Lim and Soh 1997a, b) have given similar results.

Since the classical concept of rearrangement of cambial initials in non-storeyed cambia considers occurrence of anticlinal divisions, followed by intrusive growth of the resultant initials, in excessively higher intensity than the actual requirement of the expanding cambial circumference, the excess of the cambial circumference increment was assumed to be balanced through their eliminations. Recent reports have revealed that intrusive growth and eliminations of the initials are two facets of the same process, and none of these takes part in the increase of cambial circumference. Therefore, the new concept does not refer to any excess of cambial circumference increment, which would have to be balanced by cell eliminations. Our models (Figs. 3, 4, 5, 6, 7, 8, 9) confirm that intrusive growth and eliminations of the initials do not influence the cambial circumference, as proposed in some earlier studies (Jura et al. 2006; Włoch et al. 2009).

In the examples discussed above, only a small percentage of newly formed initials, e.g. $11.5 \%$ (Bannan 1950) or $9.1 \%$ (Evert 1961), took part in increasing the cambial 
Fig. 9 A model comparing the arrangement of cells observed in tangential and transverse sections. As in previous figures, the drawings indicate the arrangement of cells before (a) and after (b) the occurrence of intrusive growth of initials \#1 and \#2, which results in partial elimination of initial \#3.

Module (i) illustrates the tangential sections in drawings $a$ and $b$ and their superposition $(a+b)$. Module (ii) illustrates enlarged area of intrusive cell growth marked with a rectangular frame on the superposition $a+b$ on module (i). The eliminated part of initial \#3 is shown with dark grey; the cell in radial files \#1 and 2 , before occurrence of intrusive growth, are bright grey, while the initial cell \#3, partly eliminated but still remaining in initial surface, is white. Module (iii) illustrates three transverse sections taken from positions indicated on modules (i) and (ii) by the horizontal lines $X, Y$ and Z

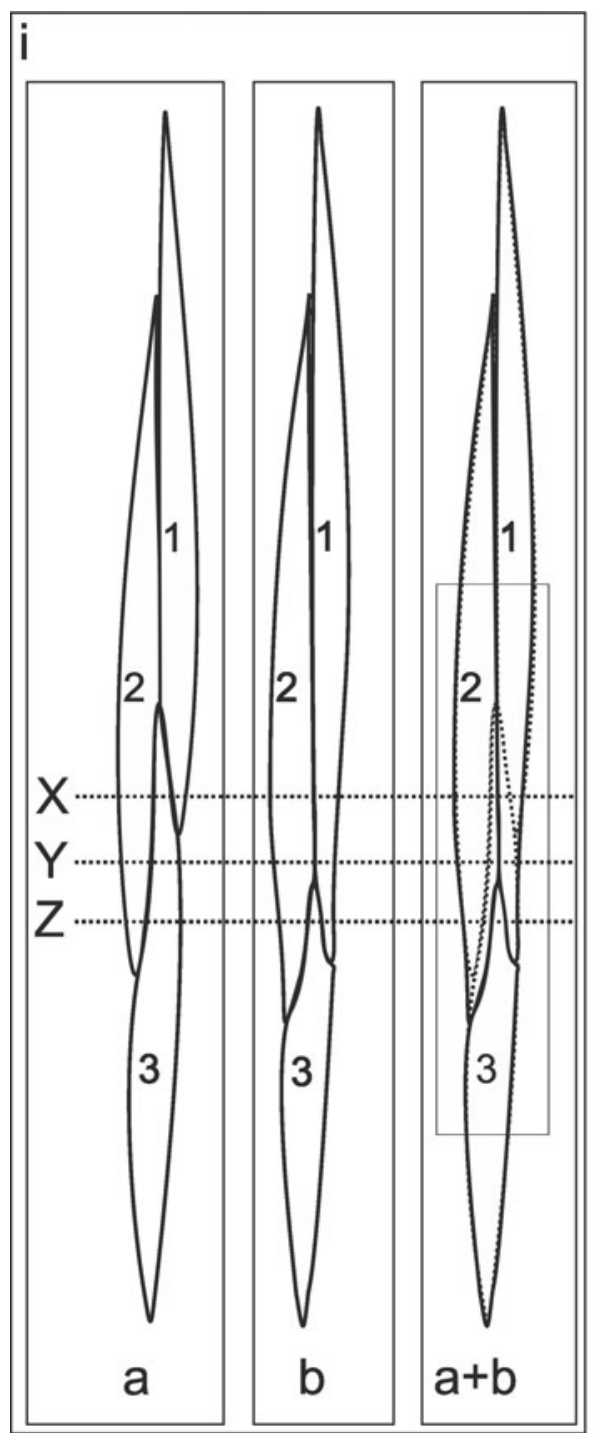

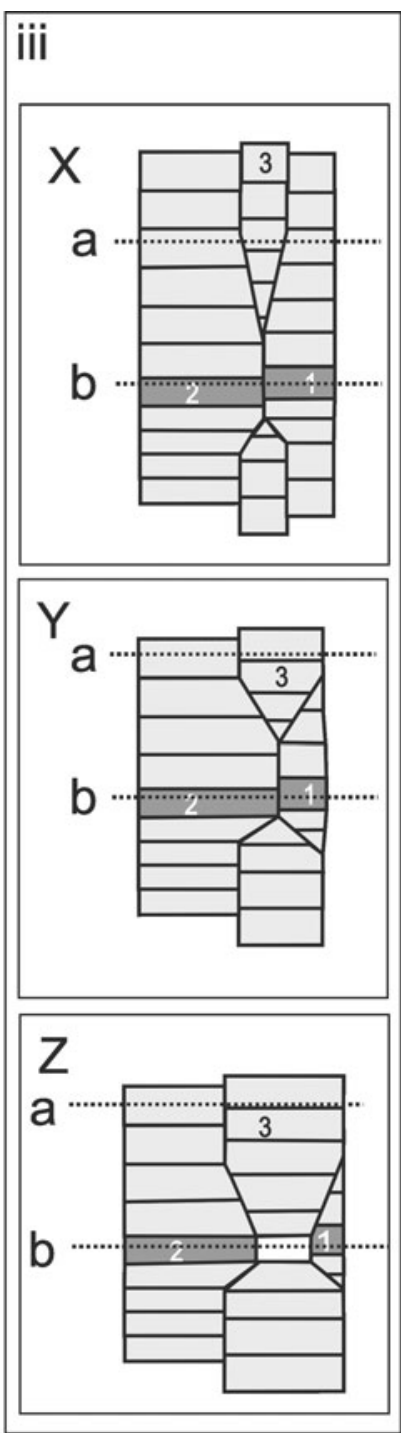

circumference. This is typical for thick trunks, where the relative increment of cambial circumference is minute. According to Karczewska et al. (2009), in a trunk of $78.5 \mathrm{~m}$ circumference concurrent with the radial increment of $100 \mu \mathrm{m}$, the relative circumferential increment is only $0.08 \%$. This means that only 31 initials were added to the circumference of this trunk, though the total number of initials was almost 40,000 . In order to meet the actual necessity, only 1 out of 1,266 initials will have to divide anticlinally. Thus, if the anticlinal divisions are meant only for contributing to the increase of the cambial circumference, these should hardly occur in the cambium of a thick trunk.

A reasonable conclusion that can be drawn from the above analysis is that the high frequency of anticlinal divisions is not related to the mechanism of the cambial circumference increment, but it helps in the rearrangement of cambial initials, as does the directed intrusive growth of anticlinally divided fusiform initials, which occur along the tangential walls of the neighbouring initial and its immediate derivative. The actual increase of cambial circumference results from symplastic growth of the resultant initials after anticlinal divisions.

Studies of mechanical forces acting through tissues (Lintilhac and Vesecky 1984; Lynch and Lintilhac 1997) have shown that orientation of division plate in dividing cells is determined by growth strains in the tissue. An ideal model of the cambium suggests that the radial tensional strains, occurring as a result of diurnal strains (Kojs and Rusin 2011), would cause periclinal divisions, whereas the tangential tensional strains, due to increase in the girth of wood cylinder would cause the sparse radial longitudinal divisions (Srivastava 1973; Karczewska et al. 2009). The pattern of cell divisions in double-storeyed cambia conforms to the ideal situation, whereas the non-storeyed cambia experience mostly oblique anticlinal divisions, the frequency of which surpasses the actual need of the 
expanding cambial-circumference. This excess of oblique anticlinal divisions, in our opinion, is a consequence of significant shearing strains produced in this type of cambium. These strains may possibly generate in storeyed cambia also, but are likely to be relaxed quickly by the directed intrusive growth of fusiform initials, which is meagre in amount and localized only around the storey borders. This results in a rapid and coordinated change of inclination and orientation of the initials in the whole storey (Włoch and Połap 1994; Kojs et al. 2003; 2004a, b; Jura et al. 2006). This type of cell rearrangement is impossible in the non-storeyed cambium, mostly because the ends of fusiform initials are located at different height levels. Apical intrusive growth has to be far greater in magnitude in this type of cambium (Kojs et al. 2004a).

In view of the observed correlation of strains in the tissue with the orientation of division plates (Lintilhac and Vesecky 1984; Lynch and Lintilhac 1997), it could be possible that shearing strains in non-storeyed cambium are not relaxed quickly and overpass some threshold level, which might cause the occurrence of oblique anticlinal divisions. If so, the occurrence of oblique anticlinal divisions may not be related to cambial circumference increment. The high frequency of anticlinal divisions exceeding the need of cambial-circumference increment confirms this inference. According to the new concept, intrusive growth of fusiform cambial initials is the main mechanism for allowing relaxation of shearing strains (Kojs and Rusin 2011). Therefore, the cells exposed to shearing strains would presumably divide anticlinally (as a result of shearing strains), and then grow intrusively (as the mechanism for relaxation of shearing strains).

We propose that the oblique anticlinal divisions are the result of shearing strains occurring locally in the tissue at a level optimal for occurrence cell divisions; the specific pattern of these strains determines also the orientation of division plates. Excessive occurrence of pseudotransverse divisions is, therefore, not related to the expansion of cambial circumference. Oblique anticlinal divisions adjust the length of fusiform initials through apical intrusive growth to the extent typical for the species. Further studies to understand the cell-growth dynamics in the cambial zone should confirm these hypotheses.

\section{Conclusions}

1. The new hypothesis for intrusive growth of cambial initials suggests that intensities of elimination and intrusive growth of the initials are equal.

2. The excess of fusiform initials, observed frequently in the non-storeyed cambia, is eliminated by intrusive growth, unlike the repeatedly asserted over-speculative concept of the two events, with an obscure explanation of the mechanism of cell elimination.

3. Instead of identifying the high frequency of anticlinal divisions with high intensity of cell eliminations, it should be identified with high intensity of intrusive growth.

4. Occurrence of intrusive growth in storeyed cambia is widespread, i.e. many cells on the initial surface undergo intrusive growth simultaneously, though its extent is quite small and confined to the borders of storeys. This allows for a rapid rearrangement without a high frequency of anticlinal divisions of fusiform initials.

5. Elimination of initials cannot be defined satisfactorily as a separate process, even though the process of intrusive growth is well defined. Intrusive growth and eliminations of the cambial initials should essentially be regarded as two facets of one and the same process.

Acknowledgments M. I. was a Visiting Professor at Plant Production Department of the College of Food and Agricultural Sciences, King Saud University of Riyadh, Saudi Arabia, during the course of this study.

Open Access This article is distributed under the terms of the Creative Commons Attribution License which permits any use, distribution, and reproduction in any medium, provided the original author(s) and the source are credited.

\section{References}

Bailey IW (1923) The cambium and its derivative tissues IV. The increase in girth of the cambium. Am J Bot 10:499-509

Bannan MW (1950) The frequency of anticlinal divisions in fusiform cambial cells of Chamaecyparis. Am J Bot 37:511-519

Bannan MW (1952) Further observations on the reduction of fusiform cambial cells in Thuja occidentalis L. Can J Bot 31:63-74

Bannan MW (1956) Some aspects of the elongation of fusiform cambial cells in Thuja occidentalis. Can J Bot 34:175-194

Bannan MW (1957) The relative frequency of the different types of anticlinal divisions in conifer cambium. Can J Bot 35:875-884

Bannan MW (1960a) Ontogenetic trends in conifer cambium with respect to frequency of anticlinal division and cell length. Can J Bot 38:795-802

Bannan MW (1960b) Cambial behaviour with reference to cell length and ring width in Thuja occidentalis L. Can J Bot 40:1057-1062

Bannan MW (1964) Tracheid size and anticlinal divisions in the cambium of Pseudotsuga. Can J Bot 42:603-631

Barlow PW, Brain P, Powers SJ (2002) Estimation of directional division frequencies of vascular cambium and in marginal meristematic cells of plants. Cell Prolif 35:49-68

Butterfield BG (1972) Developmental changes in the vascular cambium of Aeschynomene hispida Willd. N Z J Bot 10:373386

Cumbie BG (1963) The vascular cambium and xylem development in Hibiscus lasiocarpus. Am J Bot 50:944-951

Cumbie BG (1967) Developmental changes in Leitneria floridana. Am J Bot 54:414-424 
Evert RF (1961) Some aspects of cambial development in Pyrus communis. Am J Bot 48:479-488

Evert RF (2006) Esau's plant anatomy; Meristems, cells and tissues of the plant body; their structure, function and development, 3rd edn. Wiley, Hoboken

Forest L, Demongeot J (2006) Cellular modeling of secondary radial growth in conifer trees: application to Pinus radiata (D. Don). Bull Math Biol 68:753-784

Hejnowicz Z (1961) Anticlinal divisions, intrusive growth and loss of fusiform initials in nonstoried cambium. Acta Soc Bot Pol 30: $729-758$

Hejnowicz Z (1968) The structural mechanism involved in the changes of grain in timber. Acta Soc Bot Pol 37:347-365

Hejnowicz Z (1980) Tensional stress in the cambium and its developmental significance. Am J Bot 67(1):1-5

Hejnowicz Z, Brański S (1966) Quantitative analysis of cambium growth in Thuja. Acta Soc Bot Pol 35:395-400

Hejnowicz Z, Zagórska-Marek B (1974) Mechanism of changes in grain inclination in wood produced by storeyed cambium. Acta Soc Bot Pol 43:381-398

Iqbal M (1990) The vascular cambium. Wiley, New York

Iqbal M (1994) Structural and operational specializations of the vascular cambium of seed plants. In: Iqbal M (ed) Growth patterns in vascular plants. Dioscorides Press, Portland, pp 211-271

Jura J, Kojs P, Iqbal M, Szymanowska-Pułka J, Włoch W (2006) Apical intrusive growth of cambial fusiform initial along the tangential walls of adjacent fusiform initials: evidence for a new concept. Aust J Bot 54:493-504

Karczewska D, Karczewski J, Włoch W, Jura-Morawiec J, Kojs P, Iqbal M, Krawczyszyn J (2009) Mathematical modelling of intrusive growth of fusiform initials in relation to radial growth and expanding cambial circumference in Pinus sylvestris L. Acta Biotheor 57:331-348

Kojs P, Rusin T (2011) Diurnal strains in plants. In: Gliński J, Horabik J, Lipiec J (eds) Encyclopedia of agrophysics. Springer, Berlin, pp 220-224

Kojs P, Włoch W, Rusin A, Szendera W (2003) Storeyed structure of cambium as an adaptative strategy to environmental conditions in trees forming canopy and the emergent layer of the tropical rain forests. Bull Bot Gardens 12:23-29

Kojs P, Włoch W, Rusin A (2004a) Rearrangement of cells in storeyed cambium of Lonchocarpus sericeus (Poir.) DC. connected with formation of interlocked in the xylem. Trees 18:136-144

Kojs P, Włoch W, Iqbal M, Rusin A, Jura J (2004b) Readjustment of cambial initials in Wisteria floribunda (Willd.) DC to ensure the development of storeyed structure. New Phytol 163:287-297

Kramer EM (2002) A mathematical model of pattern formation in the vascular cambium of trees. J Theor Biol 216:147-158

Kwiatkowska D, Nakielski J (2011) Mechanics of the meristems. In: Wojtaszek P (ed) Mechanical integration of plant cells and plants. Springer, Heidelberg, pp 133-172
Larson PR (1994) The vascular cambium: development and structure. Springer series in wood science. Springer, New York

Lev-Yadun S (2001) Intrusive growth-the plant analog of dendrite and axon growth in animals. New Phytol 150:508-512

Lim DO, Soh WY (1997a) Cambial development and tracheid length of Dwarf Pines (Pinus densiflora and P. thunbergii). IAWA J 18(3):301-310

Lim DO, Soh WY (1997b) Development of cambium and length of vessel elements and fibres in dwarf Alnus hirsuta (Spach) Rupr. J Plant Biol 40(4):245-248

Lintilhac PM, Vesecky TB (1984) Stress-induced alignment of division plane in plant tissues grown in vitro. Nature 307:363364

Lynch TM, Lintilhac PM (1997) Mechanical signals in plant development: a new method for single cell studies. Dev Biol 181:246-256

Majumdar GP (1941) The fine structure of collenchymas cells in Heracleum sphondylium L. Proc R Soc Lond B 130:201-217

Meek GA (1976) Practical electron microscopy for biologists. Wiley, London

Nägeli C (1864) Dickenwachstum des Stengels und Anordnung der Gefässstränge bei den Sapindaceen. Beitr Wiss Bot 4:1-72

Romberger JA, Hejnowicz Z, Hill F (1993) Plant Structure: function and Development. A treatise on anatomy and vegetative development, with special reference to woody plants. Springer, Berlin

Sinnott EW, Bloch R (1939) Changes in intercellular relationships during the growth and differentiation of living plant tissues. Am J Bot 26:625-634

Srivastava LM (1973) Cambial activity in trees. Arnoldia 33:46-66

Wilczek A (2012) The formation of heterogeneous storeys in cambium on example of Laburnum anagyroides Medik. Acta Agrobotanica 65(2):47-56

Wilczek A, Jura-Morawiec J, Kojs P, Iqbal M, Włoch W (2011) Correlation of intrusive growth of cambial initials to rearrangement of rays in vascular cambium. IAWA J 32(3):313-332

Włoch W (1976) Cell events in cambium, connected with the formation and existence of a whirled cell arrangement. Acta Soc Bot Pol 45:313-326

Włoch W, Połap E (1994) Zdarzenia komórkowe i ich lokalizacja w trakcie tworzenia wzoru domenowego w kambium Tilia cordata Mill. Acta Soc Bot Pol 63(2):215-228

Włoch W, Mazur E, Kojs P (2001) Intensive change of inclination of cambial initials in Picea abies (L.) Karst. Tumours. Tress Struct Funct 15:498-502

Włoch W, Mazur E, Bełtowski M (2002) Formation of spiral grain in the wood of Pinus sylvestris L. Trees Struct Funct 16:306-312

Włoch W, Jura-Morawiec J, Kojs P, Iqbal M, Krawczyszyn J (2009) Does intrusive growth of fusiform initials really contribute to circumferential growth of vascular cambium? Botany 87:154163 